\title{
Differences between European and American IPO Markets
}

\author{
Jay R. Ritter \\ University of Florida, Gainesville FL 32611-7168, USA \\ e-mail: jay.ritter@cba.ufl.edu
}

\begin{abstract}
This brief survey discusses recent developments in the European initial public offering (IPO) market. The spectacular rise and fall of the Euro NM markets and the growth of bookbuilding as a procedure for pricing and allocating IPOs are two important patterns. Gross spreads are lower and less clustered than in the USA. Unlike the USA, some European IPOs, especially those in Germany, have when-issued trading prior to the final setting of the offer price. Current research includes empirical studies on the valuation of IPOs and both theoretical and empirical work on the determinants of short-run underpricing.
\end{abstract}

Keywords: Initial public offerings; going public; underpricing; bookbuilding; Neuer Markt

JEL Classification: $G 24 ; G 32 ; G 14 ; G 15$

\section{Introduction}

This short survey discusses recent developments in the European initial public offering (IPO) market, focusing on topics of interest to academic researchers. Differences between European and US markets are highlighted. The catalyst for this survey is the publication in this issue of European Financial Management of four articles dealing with European IPOs. All of these articles were presented at the July 2000 ABN-Amro IPO conference in Amsterdam, organised by Tjalling van der Goot of the University of Amsterdam.

Recent years have been dominated by the spectacular rise and fall of the Euro NM markets, fuelled by the busiest IPO market in European history. The 1990s also saw the growth of bookbuilding in Europe. Academic research, which in the 1980s focused on short-run underpricing and its theoretical foundations, privatisations, and mechanism design, has broadened to include valuation, long-run performance, earnings management at the time of the IPO, and operating performance issues. Researchers have documented that the gross spreads paid to underwriters are lower than in the USA. Most recently, motivated by the excesses of the internet bubble of 1999-2000,

Comments from Ralf Elsas, Tjalling van der Goot, and Alexander Ljungqvist are appreciated.

C) Blackwell Publishing Ltd. 2003, 9600 Garsington Road, Oxford OX4 2DQ, UK and 350 Main Street, Malden, MA 02148, USA. 
research has been focusing on the allocation of shares and, once again, short-run underpricing.

\section{The rise and fall of the Euro NM markets}

Table 1 lists the average first-day returns, from the offer price to the closing market price, for 38 countries around the world. The numbers that are reported are from scores of studies by different authors. Within each country, all IPOs are weighted equally. This table updates and expands the analogous table covering 25 countries in Loughran et al. (1994).

In the decade ending in 2000, there was a high volume of IPOs, especially in Europe. Aussenegg etal. (2003) report that there were 158 IPOs in 1999 and 147 IPOs in 2000 on Frankfurt's Neuer Markt and Amtlicher Handel. By contrast, in 1961-82, Germany saw only 19 IPOs, an average of less than one firm each year, according to Stehle et al. (2000). The huge fluctuations in volume from period to period suggest that market timing considerations are relatively more important than the life-cycle considerations modeled by Chemmanur and Fulghieri (1999) in determining when a firm goes public.

In 1997, Germany's Neuer Markt was founded as a market for young growth companies. Other NM markets were established in Italy (the Nuovo Mercato), the Netherlands (Nieuwe Markt), Belgium (Euro.NM Belgium), and France (the Nouveau Marché). In about 1999, these NM markets linked under the Euro NM name, but the link dissolved at the end of 2000 with the realisation that, for small companies, investor interest remains local. During its five year existence, the Nemax 50 index of Neuer Markt stocks rose from its 31 December 1997 starting value of 1000 to a peak of 9631 on 10 March 2000, before collapsing to only 313 on 7 October 2002. In 2002, the Neuer Markt announced that it was shutting down. Easdaq and Nasdaq-Europe were also started, but both were losers in the battle for market share of new listings.

This was not the first time that markets for smaller companies were developed. In 1971, Nasdaq started. In the 1980s, London's Unlisted Securities Market (USM) started, and it formally dissolved in June 1995, when it was replaced by the London Stock Exchange's Alternative Investment Market (AIM). With the exception of Nasdaq and AIM, markets for small growth companies have consistently failed following market downturns.

Before the 1990s, firms going public in Europe, especially continental Europe, tended to be much older than those going public in the USA. For example, Vandemaele (2003) reports a median age of 28 years for 220 IPOs on the French Second Marché between 1984 and 1995 compared with the median age of seven years reported by Loughran and Ritter (2003) for 6,149 US IPOs from 1980 to 2000. Even with the explosion of internet and technology-related firms going public in the 1999-2000 period, the median age of European firms going public is higher than that in the USA. Schuster (2003) reports a median age varying from 13 years in France to 31 years in Spain for IPOs from 1988 to 1998. Giudici and Roosenboom (2002) report a median age of 13 years for 1,007 European IPOs during 1995-2001, whereas Ljungqvist and Wilhelm (2003) report a median age of seven years for 2,178 US IPOs during 1996-2000. Giudici and Roosenboom also report that European IPOs are more likely to include secondary shares (shares being sold by existing shareholders) in the offering than is true for US IPOs. 


\begin{tabular}{|c|c|c|c|c|}
\hline & $\begin{array}{l}\text { Table } 1 \\
\text { Average initial returns for } 38 \text { countries. }\end{array}$ & & & \\
\hline Country & Source & $\begin{array}{l}\text { Sample } \\
\text { size }\end{array}$ & $\begin{array}{l}\text { Time } \\
\text { period }\end{array}$ & $\begin{array}{l}\text { Avg. initial } \\
\text { return }(\%)\end{array}$ \\
\hline Australia & Lee, Taylor \& Walter; Woo & 381 & $1976-1995$ & 12.1 \\
\hline Austria & Aussenegg & 83 & $1984-2002$ & 6.3 \\
\hline Belgium & Rogiers, Manigart \& Ooghe; Manigart & 86 & $1984-1999$ & 14.6 \\
\hline Brazil & Aggarwal, Leal \& Hernandez & 62 & $1979-1990$ & 78.5 \\
\hline Canada & Jog \& Riding; Jog \& Srivastava; Kryzanowski \& Rakita & 500 & $1971-1999$ & 6.3 \\
\hline Chile & Aggarwal, Leal \& Hernandez; Celis \& Maturana & 55 & $1982-1997$ & 8.8 \\
\hline China & Datar \& Mao; Gu and Qin (A shares) & 432 & $1990-2000$ & 256.9 \\
\hline Denmark & Jakobsen \& Sorensen & 117 & $1984-1998$ & 5.4 \\
\hline Finland & Keloharju; Westerholm & 99 & $1984-1997$ & 10.1 \\
\hline France & $\begin{array}{l}\text { Husson \& Jacquillat; Leleux \& Muzyka; Paliard \& Belletante; Derrien \& } \\
\text { Womack; Chahine }\end{array}$ & 571 & $1983-2000$ & 11.6 \\
\hline Germany & Ljungqvist & 407 & $1978-1999$ & 27.7 \\
\hline Greece & Kazantzis \& Thomas; Nounis & 338 & $1987-2002$ & 49.0 \\
\hline Hong Kong & McGuinness; Zhao \& Wu; Ljungqvist and Yu & 857 & $1980-2001$ & 17.3 \\
\hline India & Krishnamurti \& Kumar & 98 & $1992-1993$ & 35.3 \\
\hline Indonesia & Hanafi; Ljungqvist \& Yu & 237 & 1989-2001 & 19.7 \\
\hline Israel & Kandel, Sarig \& Wohl; Amihud, Hauser \& Kirsh & 285 & 1990-1994 & 12.1 \\
\hline Italy & Arosio, Giudici \& Paleari; Cassia, Paleari \& Redondi & 181 & $1985-2001$ & 21.7 \\
\hline Japan & $\begin{array}{l}\text { Fukuda; Dawson \& Hiraki; Hebner \& Hiraki; Hamao, Packer, \&Ritter; } \\
\text { Kaneko \& Pettway }\end{array}$ & 1,689 & $1970-2001$ & 28.4 \\
\hline Korea & Dhatt, Kim \& Lim; Ihm; Choi \& Heo & 477 & $1980-1996$ & 74.3 \\
\hline Malaysia & Isa; Isa \& Yong & 401 & $1980-1998$ & 104.1 \\
\hline Mexico & Aggarwal, Leal \& Hernandez & 37 & $1987-1990$ & 33.0 \\
\hline Netherlands & Wessels; Eijgenhuijsen \& Buijs; Ljungqvist, Jenkinson \& Wilhelm & 143 & $1982-1999$ & 10.2 \\
\hline New Zealand & Vos \& Cheung; Camp \& Munro & 201 & 1979-1999 & 23.0 \\
\hline Nigeria & Ikoku & 63 & 1989-1993 & 19.1 \\
\hline
\end{tabular}


Table 1

Continued.

\begin{tabular}{|c|c|c|c|c|}
\hline Country & Source & $\begin{array}{l}\text { Sample } \\
\text { size }\end{array}$ & $\begin{array}{l}\text { Time } \\
\text { period }\end{array}$ & $\begin{array}{l}\text { Avg. initial } \\
\text { return }(\%)\end{array}$ \\
\hline Norway & Emilsen, Pedersen \& Saettern & 68 & 1984-1996 & 12.5 \\
\hline Philippines & Sullivan \& Unite & 104 & 1987-1997 & 22.7 \\
\hline Poland & Jelic \& Briston & 140 & 1991-1998 & 27.4 \\
\hline Portugal & Almeida \& Duque & 21 & 1992-1998 & 10.6 \\
\hline Singapore & Lee, Taylor \& Walter; Dawson & 441 & 1973-2001 & 29.5 \\
\hline South Africa & Page \& Reyneke & 118 & 1980-1991 & 32.7 \\
\hline Spain & Ansotegui \& Fabregat; Otero & 99 & 1986-1998 & 10.7 \\
\hline Sweden & Rydqvist; Schuster & 332 & 1980-1998 & 30.5 \\
\hline Switzerland & Drobetz, Kammermann \& Walchli & 120 & $1983-2000$ & 34.9 \\
\hline Taiwan & Lin \& Sheu; Liaw, Liu \& Wei & 293 & 1986-1998 & 31.1 \\
\hline Thailand & Wethyavivorn \& Koo-smith; Lonkani \& Tirapat & 292 & 1987-1997 & 46.7 \\
\hline Turkey & Kiymaz; Durukan & 163 & 1990-1996 & 13.1 \\
\hline UK & Dimson; Levis; Ljungqvist & 3,122 & 1959-2001 & 17.4 \\
\hline USA & Ibbotson, Sindelar \& Ritter & 14,840 & 1960-2001 & 18.4 \\
\hline
\end{tabular}

Sources: See references listed in Loughran et al. (1994) and updated at http://bear.cba.ufl.edu/ritter/interntl.htm for pre-1993 papers and non-European papers. Recent European sources are listed in the references. Where more than one set of authors is listed as a source of information, a combined sample has been constructed. Average initial returns are constructed in different manners from study to study, although all weight each IPO equally. In general, in countries where market prices are available immediately after offerings, the one-day raw return (offer price to close) is reported. In countries where there is a delay before unconstrained market prices are reported, market-adjusted returns over an interval of several weeks are reported.

The Australian numbers for 1990-95 are from Li-Anne Woo's University of New South Wales dissertation. The updated Belgian numbers come from Sophie Manigart of the University of Ghent, with assistance from Alexander Ljungqvist of NYU. The updated Canadian numbers are from an unpublished Concordia University working paper by Lawrence Kryzanowski and Ian Rakita. The Chinese numbers are from Datar and Mao's 1997 Seattle University working paper for $1990-1996$ and Tony Gu and Jing Qin's 2000 State University of New York at Genesco working paper 'The stability of the highest short-term IPO returns: the 'A' share experience on Shanghai Stock Exchange', and represent A shares traded domestically. The Danish numbers are from Jacobsen and Sorensen (2001). The updated Finnish numbers are from a Swedish School working paper by Joakim Westerholm. The French numbers from 1993 to 1998 are from Derrien and Womack (2003). The French numbers from 1999 to 2000 are from Salim Chanine. The Greek numbers are from a chapter in Mario Levis' 1996 book Empirical Issues in Raising Equity Capital for 1987-1994 and from Christos Nounis of the National and Kapodistrian University of Athens for 1995-2002. Zhao and Wu's Hong Kong numbers are from a City University of Hong Kong working paper, and 
the 1997-2001 Hong Kong numbers are from Ljungqvist and Yu (2003). The average initial return for India is based upon IPOs with an offer price of above 10 Rupees, with the data coming from Table 5 of Krishnamurti and Kumar (2002). The Indonesian numbers for 1989-1994 are from Arosio et al. (2000), where they cite Hanafi's (1997) working paper 'Efisiensi Emisi Sahan Baru di Bursa Efek Jakarta (1989-94)'. For 1995-2001, the Indonesian numbers are from Ljungqvist and Yu (2003). Kandel et al. (1999) covers the period after Israeli auctions with no price limits became mandatory. The updated Italian numbers are from a working paper by Arosio, Giudici and Paleari of Politecnico di Milano and Universita degli Studi di Bergamo through 2000, and from Cassia, Paleari, and Redondi for 2001. The updated Japanese numbers are from Hamao et al. (2000) for 1989-1995 OTC firms, and from Kaneko and Pettway (2003) for 1996-2001. Takashi Kaneko also supplied numbers on TSE-listed IPOs from 1992 to 2000. The updated Korean numbers are from Byung Kyun Ihm's 1997 Korean Journal of Financial Management and Choi and Heo's 2000 Korean Journal of Finance articles. Numbers for several European countries for the 1992-99 period are from Ljungqvist et al. (2003). The New Zealand numbers for 1992-99 are from a University of Auckland and University of Melbourne working paper by Graeme Camp and Robert Munro. The Nigerian numbers are from a University of Southern California working paper by Ikoku. The Philippine numbers are from Michael Sullivan and Angelo Unite's 2001 Pacific-Basin Finance Journal article. The South African numbers are from Page and Reyneke's 1997 Journal of Business, Finance, and Accounting article. The updated Spanish numbers are from an ESADE working paper by Carmen Ansotegui and Jordi Fabregat. Swedish numbers for 81 IPOs from 1995 to 1998 are from Josef Schuster's LSE dissertation. The updated Taiwanese numbers are from a 1997 Journal of Financial Studies article by Lin and Sheu and a Hong Kong University of Science and Technology working paper by Liaw et al. (2000) for 52 auctions from 1995 to 1998 . For the auctions, the average first-day return of $15.06 \%$ is computed as an average of the quantity-weighted average price paid in the discriminatory auction tranche and the fixed price paid for the other tranche. Each tranche has a $50 \%$ weight. Thai numbers are from a working paper by Ravi Lonkani (Payap University) and Sunti Tirapat (Chulalongkorn University). The Turkish numbers are from Kiymaz (2000). The UK numbers for 2001 are from Ljungqvist (2001) and for 2000 are from Levis (2000) at http://www.cass.city.ac.uk/facfin/facultypages/mlevis/workingpapers/IPO_Market.pdf

In general, the numbers for a given country represent the average first-day return on IPOs where the company is headquartered in that country. For Belgium, for example, during 1991-1999, 61 companies went public, for which first-day return information is available on 41 IPOs. Of the 61 IPOs, 39 went public on the Brussels Stock Exchange, 3 on Nasdaq, 9 on Easdaq, and 10 on Euro.NM. Of the 3 Nasdaq IPOs by Belgian companies (Lernout et Hauspie, Xiekon, and ICOS Vision Systems), only Xiekon was an American Depository Share (ADS) issue. The other 2 Nasdaq IPOs have been included in the US totals, resulting in double-counting. The US number exclude ADS issues, but in general include other foreign firms going public in the USA, especially on Nasdaq. Many larger Canadian companies and Israeli tech companies went public in the USA in the 1990s. The Israeli numbers in the table are based on Israeli companies going public in Israel. 
Historically, continental Europe's IPO market has been dwarfed by the US IPO market. In 2000, however, in spite of a high volume of IPOs in the USA, continental European IPO volume exceeded that of the USA for the first time in at least several decades. When IPO volume from the UK is included, European IPO volume exceeded that of the USA in each of 1998, 1999 and 2000.

Until fairly recently, most European stock exchanges have had listing requirements that focused on financial requirements, such as having three years of positive earnings before going public. The listing standards for the Euro.NM markets have instead focused on disclosure and governance, as documented in Giudici and Roosenboom (2002, Appendix 1). In general, the new markets require periodic audited financial statements meeting international accounting standards. For IPOs listing on the new markets, insiders are generally subject to lockup provisions, restricting the sale of shares for six months or a year.

One disadvantage of being a publicly traded company is the greater transparency of company accounts to tax authorities. Giudici and Paleari (2003) examine the effect of tax incentives that the Italian government offered for companies going public. Rather than lowering taxes paid by investors on dividends or capital gains, in 1994 the Italian government passed a law lowering the corporate tax rate for newly public firms. Giudici and Paleari estimate that the lower tax rate encouraged firms to go public and report higher earnings than they otherwise would have.

\section{Mechanisms for pricing and allocating IPOs}

A number of papers have documented the decline of fixed-price mechanisms and auctions for selling IPOs in Europe, and the growth of bookbuilding (Biais and Faugeron, 2002; Sherman, 2002; and Ljungqvist etal., 2003). The mechanism for selling IPOs has been a topic of long-standing interest to researchers.

Biais and Faugeron (2002), Vandemaele (2003), and Derrien and Womack (2003) all examine the choice of mechanism for selling IPOs in France. More than any other country in the world, the French IPO market has been characterised by multiple mechanisms being used to sell IPOs without government interference in the choice. Fixed price (offre à prix ferme), auction (offre à prix minimal), and increasingly, bookbuilding (placement garanti) mechanisms have been employed by companies going public. Fixed price offerings have become uncommon in recent years, not only in France, but in other European countries as well. By fixed price mechanisms, I am referring to contracts where the offer price is set relatively early, before much information about the state of demand is known. Loughran etal. (1994) show that this tends to result in a high level of underpricing.

In the USA, bookbuilding typically starts with the setting of a file price range, say \$14-16 per share, and the commencement of a road show that might last two weeks. The difference between the minimum and maximum price is almost always \$2. During the road show, institutional investors are canvassed in regard to the state of their demand. If there is unusually weak or strong demand, a revised price range might be filed with the US Securities and Exchange Commission (SEC), say \$16-\$18. At the pricing meeting, which typically occurs in the late afternoon prior to the start of trading, the offer price can be set at up to $20 \%$ above or $20 \%$ below the most recent price range. For example, with a price range of $\$ 16-18$, the offer price can be between \$12.80 and \$21.60 without a further pricing amendment. Loughran and Ritter (2002) 
report that the final offer price is set within the original file price range about $50 \%$ of the time, with about $25 \%$ of IPOs priced below the range and $25 \%$ above the range.

By contrast, in German IPOs the price range is typically set after bookbuilding has started, with the pricing typically occurring seven trading days later (Aussenegg et al., 2003). The price range is frequently more than $€ 2$, but once set, IPOs never price above the maximum (Ljungqvist et al., 2003) in Germany, and rarely in other countries. According to Aussenegg et al., (2003), Cornelli et al., (2003), and Löffler et al. (2002), when-issued trading frequently occurs after the price range has been set, especially in Germany, where the practice appears to be most common. In general, short positions are taken by institutional investors and long positions are taken by individual investors (Dorn, 2002). All of these studies have found that the final offer price is adjusted in the direction implied by the when-issued market price, but the adjustment is fairly modest, especially for upward revisions.

The money left on the table in an IPO is defined as the number of shares offered multiplied by the first day capital gain, measured from the offer price to the closing price. In 1999-2000, huge amounts of money were left on the table, and many IPOs were heavily oversubscribed. With bookbuilding, underwriters have discretion in allocating shares. There are three views about how IPOs are allocated. These are what I call (1) the pitchbook view, (2) the academic view, and (3) the profit-sharing view. The pitchbook view, named because it is found in almost all pitchbooks (the set of slides used by underwriters when they are making a presentation to the issuing firm explaining why this underwriter should be hired as the lead underwriter), states that underwriters will use their discretion to allocate shares to institutional investors who are likely to be buy-and-hold investors. The academic view, named because the vast majority of academics analysing discretionary allocation use the Benveniste and Spindt (1989) mechanism design model, states that 'regular' investors will be allocated shares in return for truthfully revealing their estimate of share value. The profitsharing view, exposited by Loughran and Ritter (2002, 2003), states that underwriters allocate hot IPOs to investors in return for commission business. The more money that is left on the table, the higher are the profits that the underwriter receives from the resulting commission business.

A number of empirical papers have focused on allocations between institutional investors and individuals (Jenkinson and Jones, 2002; Ljungqvist and Wilhelm, 2002). In general, the recent academic literature (Cornelli and Goldreich, 2001) has framed the allocation decision in terms of the Benveniste and Spindt (1989) mechanism design model, whereas the earlier literature (Keloharju, 1993) framed the decision in terms of the Rock (1986) adverse selection model. To date, partly because of a lack of data on commission business on a client-by-client basis, there have been no direct tests of the profit-sharing view of IPO allocations.

Biais et al. (2002) analyse the optimal IPO pricing and allocation mechanism in a model where there is both asymmetric information and an agency problem between issuers and underwriters. They conclude that the discretion that underwriters have with bookbuilding results in sub-optimal outcomes for issuers relative to using auction-like mechanisms.

Torstila (2001, 2003) and Ljungqvist et al. (2003) document that the fees charged by underwriters for European IPOs are lower than those in the USA. The fees, known as the gross spread, are higher when bookbuilding is used than with auctions or fixed price offers. Holding other things constant, Ljungqvist et al. find that the gross spread is higher if there is a US tranche or if an American underwriter is the bookrunner. 
They report that US underwriters are more willing to revise the offer price upwards, however, if there is strong demand, benefiting the issuer. Torstila finds that there is less clustering of gross spreads in Europe than in the USA, where Chen and Ritter (2000) report that after 1994 almost all moderate-size IPOs have a 7\% gross spread, whether the firm going public is low risk or high risk, and whether the proceeds are $\$ 20$ million or $\$ 80$ million.

The literature examining gross spreads has noted that in a competitive equilibrium there is a tradeoff between the gross spread charged and the amount of underpricing (Ljungqvist, 2003). Furthermore, issuers are implicitly purchasing future favourable research coverage from the underwriter's analyst in many cases. If issuers consider favourable research coverage by an influential analyst to be very important, then whichever underwriter has the most influential analyst in a given industry will have market power, so it is not clear whether modelling the tradeoffs in a competitive framework is appropriate. Loughran and Ritter (2003), in the context of US IPOs, argue that issuers placed more and more attention on favourable analyst coverage as valuations increased during the 1990s, resulting in the IPO underwriting industry becoming less competitive. As a result of the reduced competition, underpricing increased, with the underwriters profiting by allocating hot IPOs in return for commission business offered by investors. An implication of this framework would be that favourable analyst coverage for European IPOs would be positively related to underpricing. I am not aware of any research that directly tests this implication.

\section{Differences between European and US practice}

One area of research that has recently been booming is that focusing on the role of analyst conflicts of interest. In the USA, issuing firms are subject to a 'quiet period', whereby from the decision to go public until 40 calendar days after going public, analysts that are affiliated with underwriters are prohibited from issuing research reports or recommendations. (Before 2002, the quiet period ended 25 days after going public.) The rationale for the quiet period is that all relevant information should be contained in the written prospectus, rather than other written documents.

The reason that analysts are important is that, with few exceptions, issuing firms place great importance on favourable analyst coverage once they are public. Because of the importance of analyst coverage in the issuing firm's objective function, investment bankers have found that they can effectively compete for deals by either implicitly or explicitly committing to have a highly regarded analyst cover a stock and issue positive recommendations. Evidence in Dunbar (2000), Krigman et al. (2001), and other studies indicates that this desire by issuing firms is so strong that underwriters with top-ranked analysts are able to charge high direct fees (gross spreads) and leave more money on the table, and still have high market shares for IPO underwriting.

To the best of my knowledge, there is relatively little research using European data examining the role of analysts in the IPO process. Most importantly, quiet period restrictions do not exist in Europe, so that both affiliated and unaffiliated analysts can and do issue research reports while an IPO is being sold, as well as immediately after going public.

Another important difference between European and US practice is that class action lawsuits are common in the USA, but rare in Europe. A class action lawsuit overcomes the free-rider problem where the suing party (the plaintiff) bears all of the 
costs but receives only part of the benefits if all shareholders are harmed. In the USA, several law firms specialise in suing corporations and their officers and directors, in what are sometimes referred to as 'strike suits', where the lawyers will receive large payments if they win their case or induce a target firm to settle. If a firm does lose a suit, the shareholders lose twice. The first loss is what motivated the suit, and the second loss is from the payments made to the winning shareholders and their lawyers. Van der Goot (2003) argues that legal risk is one of the reasons that higher quality underwriters are less likely to take riskier companies public in the Netherlands.

In practice, almost all publicly traded US firms pay for insurance, known as D\&O (directors and officers) insurance, to minimise the impact if they are successfully sued. The insurance premia do reflect company-specific risks. While there are many abuses with class action lawsuits, it is also true that there would be more corporate fraud and insider trading if this threat did not exist.

Keloharju (1993) and others have argued that the threat of lawsuits cannot be an important motivation for underpricing in countries like Finland where class action lawsuits are rare. If abuses are too extreme, as was the case with the March 2000 World On-line IPO on the Amsterdam Stock Exchange, however, lawsuits can arise. In the World On-line IPO, the company chairwoman, Nina Brink, had sold a substantial number of her shares immediately prior to the offering in a sale at a price of $€ 6$, much less than the offer price of $€ 43$, but with an additional payment contingent on the market price of the shares once trading commenced. Her transaction was economically equivalent to selling some of her shares in the open market immediately after trading commenced, and was apparently designed to avoid any lockup restrictions. The only reference to this transaction in the prospectus was a brief statement on page 99 that she had engaged in a transaction, without the details being specified. According to the May 2003 verdict in the law suit, however, the fact that a transaction had been disclosed was adequate.

A particularly interesting line of research that has been pursued by Matti Keloharju is made possible by the complete records on trading and ownership of Finnish stocks. Keloharju and Torstila (2002) use this data to examine the ownership of Finnish IPOs. In most other countries, large sample datasets have at best merely distinguished between institutional and individual investors. Keloharju and Torstila are able to examine micro-level patterns. Consistent with other studies that have used non-IPO data, they find that there is a pronounced 'home bias', in that people tend to buy the stock of firms that they are familiar with. Since people tend to be familiar with stocks that are positively correlated with their human capital or other assets, this home bias results in a higher variance of wealth changes than would be true if they had more diversified assets.

\section{Valuation, control, and long-term returns}

A number of recent papers focus on valuation-related topics. Pagano et al. (1998) is probably the most prominent paper to focus on valuation and its effect on a firm's decision to go public. In general, very little academic research has focused on valuation issues, with the large preponderance of research focusing on the difference in valuations between the offer price and the first-day close (the first-day return).

There are two general approaches to valuation. The first approach is to examine the valuation of individual companies or groups of companies, either using discounted cash flow analysis or comparable firm multiples. Because forecasts of future cash 
flows are rarely available, and even if forecasts are available, they may be highly unreliable (think internet stocks), IPOs are typically valued using comparable firm multiples. Roosenboom and Van der Goot (2003) use valuation analysis to examine the effect of takeover defences on firm value at the time of going public, and Knauf et al. (2003) examine whether accounting information helps explain the valuation of internet IPOs at the peak of the boom in internet IPOs.

Chanine (2002) examines the offer price relative to the value implied by comparable firms for 257 IPOs. Chanine finds that technology firms are priced at a larger discount than non-tech firms, consistent with the higher first-day returns on tech IPOs.

In Sweden, the vast majority of IPOs involve dual-class shares, where the stock sold to the public has inferior voting rights. Holmén and Högfeldt (2003) present evidence that the controlling shares with superior voting rights are subsequently never sold in anything other than block transactions, preserving the control. Since shares with inferior voting rights typically sell at a discount, as documented by Zingales (1994) for Italian firms, presumably the Swedish shares should sell at a lower market-to-book ratio than they otherwise would. Holmén and Högfeldt report that this is indeed the case. They argue that investors in Sweden are not as concerned about wealth transfers to controlling shareholders as they are worried about inefficient investment decisions.

Brennan and Franks (1997) examine the evolution of control in UK IPOs, where dual-class shares are uncommon. They report that, for a sample of 43 IPOs from 1986 to 1989 , there is a substantial dilution of control over time. Goergen and Renneboog (2003) address the difference in control between German and UK corporations using data from IPOs during the six years after flotation. They report that pyramid structures in Germany permit the retention of control.

The second approach to valuation is to examine not the level of valuation, but the long-run returns, which can be thought of as changes in valuation over time. This addresses the question of whether firms were valued appropriately, although large samples over long time periods are generally required to find statistically significant abnormal performance. Because IPOs tend to go public in industry-specific waves (once again, think of the internet IPOs from 1999 to 2000), it is difficult to separate out bad luck from ex ante overvaluation if subsequent returns are low. Unlike the USA, where samples of thousands of IPOs over many decades are available to measure long-term returns, relatively small sample sizes exist for most European studies. In Table 1, Japan, the UK, and the USA are the only countries where the sample size is over 500 IPOs. Several studies use the cross-sectional distribution of long-run returns to examine whether the market correctly evaluated information at the time of going public. Roosenboom et al. (2003), for instance, find that long-term returns are more negative, the greater are the accruals in reported earnings, for a sample of IPOs from the Netherlands. The results are similar to those reported by Teoh et al. (1998) for a sample of US IPOs.

Many studies have examined the long-run returns on IPOs in various countries. Many of these studies are summarised in Jenkinson and Ljungqvist (2001, Table 2.2). Schuster (2003) reports cumulative market-adjusted returns (CARs), with monthly rebalancing over 36 months, for seven continental European countries for IPOs from January 1988 to January 1998. For all seven countries (France, Germany, Italy, the Netherlands, Spain, Sweden, and Switzerland), he reports negative 36-month CARs varying from $-11.7 \%$ in Germany to $-41.8 \%$ in Italy.

Another area of current research concerns IPOs from the former communist-bloc countries of eastern Europe. Jelic and Briston (2003) examine the first-day and 
long-run returns on Polish IPOs, and Jelic et al. (2003) examine the new IPO market in Poland, Hungary, and the Czech Republic. Following the fall of the iron curtain in 1989-1991, a variety of mechanisms have been used to privatise formerly state-owned enterprises in Eastern Europe (Claessens, 1997). In general, the market value of the individual companies has been miniscule relative to the privatisations in Western Europe during the 1980s and 1990s, when most state-owned telecommunications companies were privatised.

\section{Conclusions}

This brief survey has discussed recent developments in the European initial public offering (IPO) market, focusing on topics of interest to academic researchers. It complements my other recent surveys (Ritter and Welch, 2002; Ritter, 2003) that, due to space constraints, are rather US-centric. A more extensive survey of the IPO literature can be found in Jenkinson and Ljungqvist (2001). Any survey is by its nature static, and I cannot predict how future practice and research on European IPOs will develop. Fortunately, the excellent website 'IPOs in Europe', at http:// www.esterni.unibg.it/siti_esterni/sige/iposineurope/, contains links to many European IPO researchers.

This survey has been unable to cover all of the current research being done with a European IPO focus. In particular, I have only briefly discussed the evidence on the long-run performance of European IPOs. During 1999-2000 both record volume and record underpricing were seen, followed by the lowest volume of IPOs since the depressed markets of 1974-79. Many research questions remain unanswered. For example, models of underpricing from the 1980s and early 1990s emphasised equilibrium underpricing with asymmetric information. The extreme underpricing of the internet bubble period of 1999-2000 has resurrected interest in short run underpricing. As Ritter and Welch (2002) argue, this extreme underpricing is more likely to be explained with models emphasising agency conflicts and behavioural explanations than on the basis of asymmetric information. Today, questions that are being addressed include how IPOs are allocated, and what causes the severe fluctuations in volume in IPO markets. Even if these questions are answered, however, new questions will develop, since financial markets evolve rather than remaining unchanged.

\section{References}

Almeida, M. and Duque, J., 'Ownership structure and initial public offerings in small economies: the case of Portugal', Working Paper (Universidade Tecnica de Lisboa, 2000).

Amihud, Y., Hauser, S. and Kirsh, A., 'Allocations, adverse selection, and cascades in IPOs: evidence from the Tel Aviv Stock Exchange', Journal of Financial Economics, Vol. 68, 2003, pp. 137-158.

Ansotegui Olcoz, C. and Fabregat Feldsztajn, J., 'Initial public offerings on the Spanish stock exchange', Working Paper (ESADE, 2000).

Arosio, R., Giudici, G. and Paleari, S., 'What drives the initial market performance of Italian IPOs? An empirical investigation on underpricing and price support', Working Paper (University of Bergamo, 2000).

Aussenegg, W. 'Short and long run performance of IPOs in the Austrian stock market', Working Paper (Vienna Institute of Technology, 2000).

C) Blackwell Publishing Ltd, 2003 
Aussenegg, W., Pichler, P. and Stomper, A. 'IPO pricing with bookbuilding and a when-issued market', Working Paper (Vienna Institute of Technology, 2003).

Benveniste, L. M. and Spindt, P. A., 'How investment bankers determine the offer price and allocation of new issues', Journal of Financial Economics, Vol. 24, 1989, pp. 343-361.

Biais, B., Bossaerts, P. and Rochet, J.-C., 'An optimal IPO mechanism', Review of Financial Studies, Vol. 69, 2002, pp. 117-146.

Biais, B. and Faugeron, A. M., 'IPO auctions: English, Dutch, ... French and internet', Journal of Financial Intermediation, Vol. 11, 2002, pp. 9-36.

Brennan, M. and Franks, J., 'Underpricing, ownership and control in initial public offerings of equity securities in the UK', Journal of Financial Economics, Vol. 45, 1997, pp. 391-413.

Celis, C. and Maturana, G., 'Initial public offerings in Chile', Revista Abante, Vol. 1, 1998, pp. $7-31$.

Chanine, S., 'Issuing firm value and IPO discount: are investment bank valuation models accurate?' Working Paper (Audencia-Nantes School of Management, 2002).

Chemmanur, T. J. and Fulghieri, P., 'A theory of the going-public decision', Review of Financial Studies, Vol. 12, 1999, pp. 249-279.

Chen, H.-C. and Ritter, J. R., 'The seven percent solution', Journal of Finance, Vol. 55, 2000, pp. 1105-1131.

Claessens, S., 'Corporate governance and equity prices: evidence from the Czech and Slovak Republics', Journal of Finance, Vol. 52, 1997, pp. 1641-1658.

Cornelli, F. and Goldreich, D. 'Bookbuilding and strategic allocation', Journal of Finance, Vol. 56, 2001, pp. 2337-2369.

Cornelli, F., Goldreich, D. and Ljungqvist, A., 'Pre-IPO markets', Working Paper (London Business School, 2003).

Dawson, S., 'Better late than never?' Pulses, the Magazine of the Stock Exchange of Singapore, May 31, 2003, pp. 21-22.

Derrien, F. and Womack, K. L., 'Auctions vs. bookbuilding and the control of underpricing in hot IPO markets', Review of Financial Studies, Vol. 16, 2003, pp. 31-61.

Dorn, D. 'Does sentiment drive the retail demand for IPOs?' Working Paper (Columbia University, 2002).

Drobetz, W., Kammermann, M. and Wälchli, U., 'Performance of initial public offerings: the evidence from Switzerland', Working Paper (University of Basel, 2003).

Dunbar, C., 'Factors affecting investment bank initial public offering market share', Journal of Financial Economics, Vol. 55, 2000, pp. 3-41.

Durukan, M. B., 'The relationship between IPO returns and factors influencing IPO performance: case of the Istanbul Stock Exchange', Managerial Finance, Vol. 28, 2002, pp. 18-38.

Giudici, G. and Paleari, S., 'Should firms going public enjoy tax benefits? An analysis of the Italian experience in the 1990s', European Financial Management, Vol. 9, 2003, this issue, pp. 513-534.

Giudici, G. and Roosenboom, P., 'Pricing initial public offerings in Europe: what has changed?' Working Paper (Erasmus University, 2002).

Goergen, M. and Renneboog, L., 'Why are the levels of control (so) different in German and U.K. companies? Evidence from initial public offerings', Journal of Law, Economics, and Organization, Vol. 19, 2003, pp. 141-175.

Hamao, Y., Packer, F. and Ritter J., 'Institutional affiliation and the role of venture capital: evidence from initial public offerings in Japan', Pacific-Basin Finance Journal, Vol. 8, 2000, pp. 529-558.

Holmén, M. and Högfeldt, P., 'A law and finance analysis of initial public offerings', Working Paper (Stockholm University, 2003).

Jacobsen, J. and Sorensen, O., 'Decomposing and testing long-run returns, with an application to initial public offerings in Denmark', European Financial Management, Vol. 7, 2001, pp. 393-415.

Jelic, R. and Briston, R., 'Privatisation initial public offerings: the Polish experience', European Financial Management, Vol. 9, 2003, this issue, pp. 457-484. 
Jelic, R., Briston, R. and Aussenegg, W. 'The choice of privatization method and the financial performance of newly privatized firms in transition economies', Journal of Business Finance and Accounting, forthcoming, 2003.

Jenkinson, T. and Jones, H., 'Bids and allocations in European IPO bookbuilding', Working Paper (Oxford Saïd School, 2002).

Jenkinson, T. and Ljungqvist, A., Going Public: the Theory and Evidence on How Companies Raise Equity Finance (Oxford: Oxford University Press, 2001).

Kandel, S., Sarig, O. and Wohl, A., 'The demand for stocks: an analysis of IPO auctions', Review of Financial Studies, Vol. 12, 1999, pp. 227-247.

Kaneko, T. and Pettway, R. H., 'Auctions versus book-building of Japanese IPOs', PacificBasin Finance Journal, forthcoming, 2003.

Kazantzis, C. and Thomas, D., 'The IPO puzzle and institutional constraints: evidence from the Athens stock market', in M. Levis (ed.) Empirical Issues in Raising Equity Capital (Amsterdam: Elsevier, 1996).

Keloharju, M., 'The winner's curse, legal liability, and the long-run performance of initial public offerings', Journal of Financial Economics, Vol. 34, 1993, pp. 251-277.

Keloharju, M. and Torstila, S., 'The distribution of information among institutional and retail investors in IPOs', European Financial Management, Vol. 8, 2002, pp. 357-372.

Kiymaz, H., 'The initial and aftermarket performance of IPOs in an emerging market: evidence from Istanbul Stock Exchange', Journal of Multinational Financial Management, Vol. 10, 2000, pp. 213-227.

Knauff, P., Roosenboom, P. and van der Goot, T., 'Is accounting information relevant to valuing European internet IPOs?' New Venture Financing (Amsterdam: North-Holland, 2003).

Krigman, L., Shaw, W. and Womack, K., 'Why do firms switch underwriters?' Journal of Financial Economics, Vol. 60, 2001, pp. 245-284.

Krishnamurti, C. and Kumar, P., 'The initial listing performance of Indian IPOs', Managerial Finance, Vol. 28, 2002, pp. 39-51.

Lee, P. J., Taylor, S. L. and Walter, T. S., 'IPO underpricing explanations: Implications from investor application and allocation schedules', Journal of Financial and Quantitative Analysis, Vol. 34, 1999, pp. 425-444.

Levis, M., 'The U.K. IPO market 2000', Working Paper (City University, 2000).

Liaw, G., Liu, Y. J. and John Wei, K. C., 'On the demand elasticity of initial public offerings: an analysis of discriminatory auctions', Working Paper (Hong Kong University of Science and Technology, 2000).

Ljungqvist, A., 'Conflicts of interest and efficient contracting in IPOs', Working Paper (New York University, 2003).

Ljungqvist, A., Jenkinson, T. and Wilhelm, W., 'Global integration in primary equity markets: the role of U.S. banks and U.S. investors', Review of Financial Studies, Vol. 16, 2003, pp. 63-99.

Ljungqvist, A. and Wilhelm, W., 'IPO allocations: discriminatory or discretionary?', Journal of Financial Economics, Vol. 65, 2002, pp. 167-201.

Ljungqvist, A. and Wilhelm, W., 'IPO pricing in the dot-com bubble', Journal of Finance, Vol. 58, 2003, pp. 723-752.

Ljungqvist, A. and $\mathrm{Yu}, \mathrm{X}$., 'Stock market development, liquidity, and corporate governance', Working Paper (New York University, 2003).

Löffler, G., Panther, P. F. and Theissen, E., 'Who knows what when? The information content of preIPO market prices', Working Paper (University of Frankfurt/Main, 2002).

Loughran, T. and Ritter, J. R., 'Why don't issuers get upset about leaving money on the table in IPOs?' Review of Financial Studies, Vol. 15, 2002, pp. 413-443.

Loughran, T. and Ritter, J. R., 'Why has IPO underpricing changed over time?' Working Paper (University of Notre Dame and University of Florida, 2003).

Loughran, T., Ritter, J. R. and Rydqvist, K., 'Initial public offerings: international insights', Pacific-Basin Finance Journal, Vol. 2, 1994, pp. 165-199. 
Nounis, C., 'Greek initial public offerings, 1994-2002', Working Paper (National and Kapodistrian University of Athens, 2003).

Otero, S. Á., 'Initial public offerings: the Spanish case', Working Paper (Oviedo University, 2003).

Pagano, M., Panetta, F. and Zingales, L., 'Why do firms go public? An empirical analysis', Journal of Finance, Vol. 53, 1998, pp. 27-64.

Ritter, J. R., 'Investment banking and securities issuance', in Constantinides, Harris and Stulz (eds) Handbook of the Economics of Finance (Amsterdam: North-Holland, 2003, chapter 5).

Ritter, J. R. and Welch, I., 'A review of IPO activity, pricing, and allocations', Journal of Finance, Vol. 57, 2002, pp. 1795-1828.

Rock, K., 'Why new issues are underpriced', Journal of Financial Economics, Vol. 15, 1986, pp. 187-212.

Roosenboom, P., van der Goot, T. and Mertens, G., 'Earnings management and IPOs: evidence from the Netherlands', International Journal of Accounting, forthcoming, 2003.

Roosenboom, P. and van der Goot, T., 'Takeover defences and IPO firm value in the Netherlands', European Financial Management, Vol. 9, 2003, this issue, pp. 485-512.

Schuster, J. A., 'IPOs: insights from seven European countries', Working Paper (London School of Economics, 2003).

Sherman, A. E., 'Global trends in IPO methods: book building vs. auctions', Working Paper (University of Notre Dame, 2002).

Stehle, R., Ehrhart, O. and Przyborowsky, R., 'Long-run stock performance of German initial public offerings and seasoned equity issues', European Financial Management, Vol. 6, 2000, pp. 173-196.

Teoh, S. H., Welch, I. and Wong, T. J., 'Earnings management and the long-run performance of initial public offerings', Journal of Finance, Vol. 53, 1998, pp. 421-449.

Torstila, S., 'What determines IPO gross spreads in Europe?' European Financial Management, Vol. 7, 2001, pp. 523-541.

Torstila, S., 'The clustering of IPO gross spreads: international evidence', Journal of Financial and Quantitative Analysis, forthcoming, 2003.

Van der Goot, T., 'Risk, the quality of intermediaries and legal liability in the Netherlands IPO market', International Review of Law and Economics, forthcoming, 2003.

Vandemaele, S., 'Choice of selling mechanism at the IPO: The case of the French Second Market', European Financial Management, Vol. 9, 2003, this issue, pp. 435-455.

Westerholm, J., 'The activity of the underwriter in initial public offerings: evidence from the limit order book of the Helsinki Stock Exchange', Working Paper (Swedish School of Economics and Business Administration, 2000).

Zingales, L., 'The value of the voting right: a study of the Milan Stock Exchange experience', Review of Financial Studies, Vol. 7, 1994, pp. 125-148. 